\title{
2019 Activities Report
}

\author{
Michael Meeks \\ Caddo Culture Club
}

Follow this and additional works at: https://scholarworks.sfasu.edu/ita

Part of the American Material Culture Commons, Archaeological Anthropology Commons, Environmental Studies Commons, Other American Studies Commons, Other Arts and Humanities Commons, Other History of Art, Architecture, and Archaeology Commons, and the United States History Commons

Tell us how this article helped you.

This Article is brought to you for free and open access by the Center for Regional Heritage Research at SFA ScholarWorks. It has been accepted for inclusion in Index of Texas Archaeology: Open Access Gray Literature from the Lone Star State by an authorized editor of SFA ScholarWorks. For more information, please contact cdsscholarworks@sfasu.edu. 


\section{Activities Report \\ Creative Commons License \\ (c) $(1)(9)$}

This work is licensed under a Creative Commons Attribution-NonCommercial 4.0 International License 


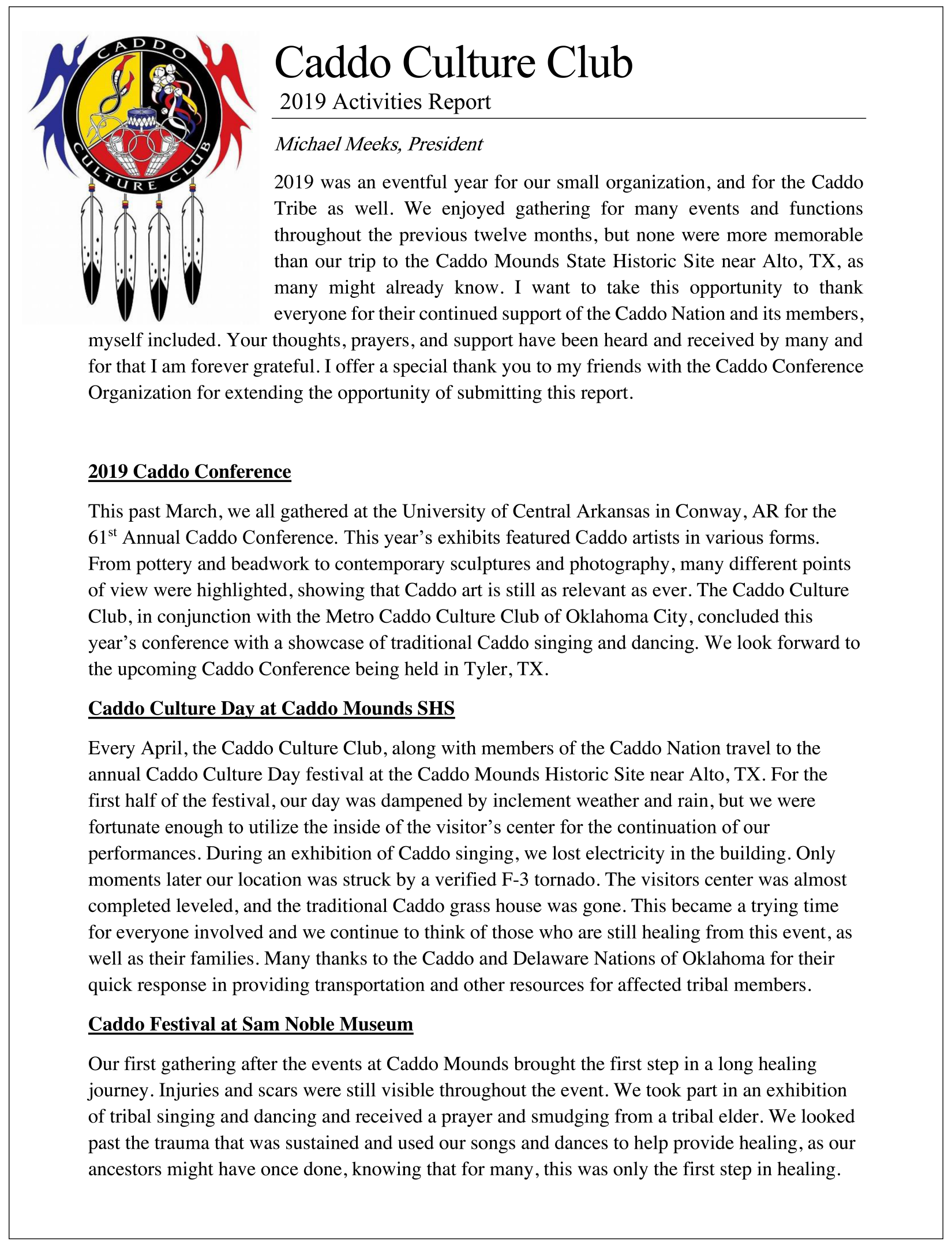




\section{Caddo Culture Club Annual Dance and Murrow Family Annual Powwow}

In June, we gathered at the Caddo Tribal dance grounds for our $27^{\text {th }}$ Annual Dance and at the Murrow family dance grounds for their annual powwow. Our event featured the 2017-2019 Delaware Nation Princess, Ms. Angel Kionute, as an honored guest for her devotion to our organization's events. At the Murrow Family Powwow, we took part in three nights of singing and dancing that featured intertribal showcases and exhibitions from members of the Kiowa tribe's Oh-Ho-Mah Society. We are currently underway in the planning process of our 2020 annual dance. We welcome and invite everyone to this event!

\section{Thanksgiving and Christmas Holidays}

During the Fall and Winter seasons, we organized a Fall Caddo Social Dance and Holiday toy drive for the community. While Thanksgiving generally carries negative connotations for many First Nations people, we do not let that stop us from having a great feast! At our November Social Dance, we provided a full holiday meal to everyone who was present and spent the greater part of the evening rejoicing in traditional Caddo singing and dancing. This event helped start our holiday toy drive. This year, we provided toys to the Wichita Community Church in Anadarko, OK for their efforts in providing gifts for underprivileged children in the local community.

\section{Grand Reopening at Caddo Mounds}

On January 11, 2020 many people returned to the Caddo Mounds Historic Site for their grand reopening. A temporary visitor's center has been reopened and the traditional Snake Woman's garden has been cultivated once again. In honor of their efforts, and as a sign of healing, a cedar tree that is a traditional sign to the Caddo people was planted in the garden. We look forward to returning to Caddo Mounds and one day seeing a new visitors center and Caddo grass house.

\section{Many thanks, again, to the Caddo Conference Organization for their continued support of Caddo culture, heritage, and history.}

The Caddo Culture Club is a non-profit organization located in Binger, Oklahoma that works to preserve and teach traditional Caddo singing and dancing. You can find us on Facebook (@CaddoCultureClub) to see our upcoming events and activities or for more information about us! 